\title{
ISRAELI-PALESTINIAN RELATIONS: WAGING FOR PEACE OR LOST DESPERATELY
}

\author{
Elena Tllovska-Kechedji \\ Assistant professor, Ph.D. Faculty of Law, University "St. Kliment Ohridski" - Bitola, Macedonia \\ E-mail: elena-tilovska-kechegi@hotmail.com, elena.tilovska-kechegi@uklo.edu.mk
}

\begin{abstract}
Since the beginning of the $20^{\text {th }}$ century, the Israeli-Palestinian unsettled issue began to escalate into a conflict. The small piece of land couth the eye of political interests and became a very big problem not only for the surrounding neighbors but for the whole Middle East and the world. Jewish population claims that the land is theirs and they have the right to be there due to historical and biblical argumentation. Palestinians consisted the majority of the population on this territory and resided on this lands since they can remember. In the $19^{\text {th }}$ century the Palestine region was part of Ottoman rule and in that period this territory did not represent an important political unit. After World War I Britain entered the region and it decreed over the area that now comprises Israel, West Bank, and Gaza Strip. Britain's presence brought many instabilities due to its own political interests. Later on, as a result of the atrocities afflicted upon Jews in Europe, Jews moved from Europe and settled in Israel and also due to the Zionism which is a political movement. As the political interest over the region escalated the visible solution for the problem was weakened. The Oslo Peace Accord for the first time gave the sparkle of hope to both sides. Even though the Accord was not successful it still presented an idea for peace and a chance for a solution of the conflict. The situation up till today does not give even the slightest hope for resolution. The conflict still flames with many deaths on both sides. The influence of the European Union, United Nations and mostly from the United States is visible but without inflicting drastic changes towards a solution. The newest decision of President Trump to recognize Jerusalem as the capital of Israel triggered, even more, an escalation of the fire, and brought more anger and despair in the Middle East. The conflict is clearly a political one and the question is whether there is an objective solution possible. The possible scenarios of a two state and one state will most probably never occur because the solution lies in the hands of both parties settling on a joint and mutual understanding of the problem and settling on common grounds.
\end{abstract}

Keywords: Israel - Palestine conflict, Oslo Accords, negotiations, proposals for solutions.

\section{INTRODUCTION TO THE ISRAEL - PALESTINIAN CONFLICT}

In 1882 the Palestine region and the district of Jerusalem were under the Ottoman rule. The district of Jerusalem was and still is very important due to the cities of Jerusalem and Bethlehem, which are the religious centers for Muslims, Christians, and Jews. In 1878, Jerusalem, Nablus and Acre districts consisted of 462.465 citizens: Muslims were 403,795, 43,659 were Christians and 15,011 were Jews. Most of the 
people living on the land were attached to it due to the religious significance for them not due to national or political beliefs. At the beginning of the twentieth century, the territory of Palestine had become very attractive to political and nationalistic movements. The European powers were very much interested in the region and they invaded it. In 1915-1916 the British high commissioner Mc Mahon convinced Husayn ibn Ali an Ottoman governor of Mecca and Medina to help them revolt against the Ottoman Empire, the British promised that if the Arabs help them the British government will support the creation of an Arab state under Hashemite rule (Palestine territory included). The uprising was successful and Britain ruled the region. Britain and France convinced the League of Nations to gain mandates on the territory. Britain earned a mandate over Iraq, the area of Israel, the West Bank, the Gaza Strip, and Jordan. (Beinin Joel and Hajjar, Lisa, pp.2) But Britain was unfaithful to the Arabs and made other promises like the one to Israel. On November 2, 1917, Lord Arthur J. Balfour, (a British foreign secretary) wrote to Rothschild (a Jewish leader) that the Majesty will support a Jewish state. This promise is known as the Balfour declaration. (Pressman, Jeremy pp. 3) The declaration was presented in a form of a letter:

"His Majesty's Government view with favor the establishment in Palestine of a national home for the Jewish people and will use their best endeavors to facilitate the achievement of this object, it being clearly understood that nothing shall be done which may prejudice the civil and religious rights of existing non-Jewish communities in Palestine, or the rights and political status enjoyed by Jews in any other country". ("The Balfour Declaration: A century of injustice")

This was the first trigger to the Israeli-Palestine conflict. And the conflict was mostly triggered by the British who promised one thing and acted in a more convenient way for them. Furthermore, in the letter it is stated that all other non-Jewish people will be respected and allowed to live on the land of Israel this was not the case, later on all non-Jewish population was evicted from the territory and Jews began to inhabit the areas of the Arabs, in order to settle the territory and to be the majority of the population and with this action hoping to get the whole territory for themselves.

Furthermore in 1921, the British divided the Palestine region in two: East of Jordan River became the Emirate of Transjordan and west of Jordan became the Palestine Mandate. In this period due to the war in Europe, Jews began to settle more and more in Israel which was opposed by the Arabs. In the period of 1920-21 conflict broke out between Arabs and Jews because the Jewish National Fund purchased a lot of land from Arabs who did not live anymore on the territory and many people who lived on the territory were forced out from their homes. This escalated, even more, the violent confrontations. In 1928 Muslims and Jews in Jerusalem began to fight over who has the religious rights at the Western Wall which is sacred for both sides. (Beinin Joel and Hajjar, Lisa, pp.2) The conflict that begun as non-religious and non-National became exactly that. One problem led to another. The tiniest misunderstanding was a trigger for more violence between the people who lived in the territory. The misunderstandings and conflicts are always used by extremist groups on both sides that flame the charcoal even more.

In February 1947, Britain asked the United Nations (the League of Nations) to address the issue of Palestine region since Britain had no interest there anymore. The UN Special Committee of Palestine (UNSCOP) suggested the Palestine region be divided into two states, a Jewish one, and an Arab one. UNSCOP suggested the Arab state would be about $42 \%$ of Palestine territory and the Jewish one about $55 \%$ of the territory, the remaining territory including Jerusalem, would be an international zone. The Jewish state would be a home to around 500,000 Jews and 400,000 Arabs. (Therefore the population would be mixed, the Arab population will not be evicted). On November 1947, UNSCOP report was approved by UN General Assembly as Resolution 181. The Jews accepted the plan for separation, but the Arabs rejected the idea, and the fighting continued. Israel used its perfect chance and declared its independence on May 14, 1948. (Pressman, Jeremy, pp. 4) Israelis were prepared militarily, politically and strategically for their decision and action and they got what they wanted. On the other hand the Arabs uncertainty, ambivalence, not knowing what they want led them to pass the only chance they got to have a state of their own, a proclaimed nation without a war. This was the worst decision the Arabs made, it was a chance to be accepted by the International community and due to lack of leadership, common understanding, greediness to have all or nothing, and they passed their chance.

In 1948-1949 the land was divided into three parts: The State of Israel, the West Bank (of the Jordan River) and the Gaza Strip. This is a small area of 10.000 square miles. Jewish claims for the territory are based on the Abraham promise in the bible which is part of the Jewish kingdoms of Israel and Judea. Arabs claims are based on their residence in the country and they represented the majority of the population until 1948. Also, Arabs have their biblical argument that Abraham's son Ishmael is the forefather of the Arabs, and therefore they have also the right to the land. (Beinin Joel and Hajjar, Lisa, pp.1). But the logical explanation is that both of the nations have the right to be there as part of their history, which constitutes who and what they 
are, they just need to find a common ground and understanding of how they will settle their territorial differences and live there. Because both of the nations lived there in peace between each other before the political ideologies and nationalist movements spread in the region.

In 1949 Israel due to the fighting and wars got control of $78 \%$ of the Palestine territory. Jerusalem was not anymore under international control. Israel controlled the west of the city of Jerusalem and Transjordan controlled the east part of the city, Egypt occupied the Gaza Strip. The same year Israel signed a truce with Egypt, Jordan, Lebanon, and Syria. (Pressman, Jeremy, pp. 4) But these ceasefires in the region did not last for long.

In the 80's and 90's the Israel politics changed in regards to their neighbors, instead of fighting they concluded peace treaties. On 25 April 1982 Israel signed the Israel-Egypt Peace Treaty. At the Madrid Conference in 1991 bilateral negotiations were conducted between Israel, Palestine, and Syria to achieve some kind of agreement. Israel and Palestine on 13 September 1993 signed a declaration of Principles or the "Oslo Accords" supporting the two-state solution. Between, 1994-1999 six agreements were concluded for the conditions that should have led to the solution. Furthermore in 1994 was signed the Israel-Jordan Peace Treaty. The peace treaties conducted with the neighbors lasted but the one with Palestine was nowhere near the beginning. In the period of 2001-2005, the violence escalated between the two nations again. In 2005 Israel disengaged from the Gaza Strip evacuating its citizens and the military but maintaining control over the entrance in the Gaza Strip. In 2006 on the Palestinian elections won Hamas which froze relations between the two nations once again. Furthermore, in 2006, Israel engaged in a 34-day conflict with Hezbollah in Lebanon and a 23-day war with Hamas in the Gaza Strip in 2008-2009. In November 2012 Israel engaged in a seven-day conflict with Hamas. Some sort of negotiations begun in July 2013 but were suspended in April 2014. This was fourth in a row efforts to resolve the conflict since Camp David in 2000, but three months later Hamas bombarded Israel which led to 51-day conflict. (The World Factbook, pp. 2) The conflicts between the two nations are on and off for the past 100 years, there is not one side to blame, it all depends on the leader's beliefs and views. A possible solution is not visible in the near future as long as both sides don't decide what they want and firmly sit down and discuss certain questions that are aching the problem. But this problem does not exist only between Israel-Palestine as it is obvious this kind of uprisings, conflicts rage in the whole territory of the Middle East if one conflict stops others will rise somewhere nearby.

\section{THE TRIGGERS TO THE ISRAELI-PALESTINIAN CONFLICT}

In the period of the $20^{\text {th }}$ century as was presented above, the Middle East region was introduced with new ideas, movements, believes that boosted the rise of a different era. The idea of nationalism was born, the idea of self-governing or statehood, the Zionist movement and much more constituted as triggers to the conflict of Palestine and Israel.

\subsection{Nationalism and Statehood}

A nation constitutes a group of people who share a heritage, a culture, a system of beliefs. (Luxenberg, Alan pp.1) In the nineteenth century, large groups of people identified themselves as nations and demanded national rights, the right to self-rule, and to have a state of their own. So both Jews and Palestinians started to develop a national consciousness and national goals. Jews were spread around the world due to the Nazis, the Jewish national movement Zionism exhorted of a place where Jews could be together and Palestine seemed the right place because it had the historical meaning for the Jewish people. (Beinin Joel and Hajjar, Lisa, pp.1) Arabs that lived on Palestine territory were always part of the region, the history and origin of the territory are tied to them, as a nation they were not integrated there they were part of that land. Therefore, their nationhood is not in question. Neither is the Jewish nation in question. What is questionable here is why they both cannot settle to live on the territory as they lived before Nationalism developed as a movement. Both nations can discuss the borders and create two nations and two states on this territory. And the Holy city can be a holy land, not an entity to someone or something it will be a holy land to the three religions, and to everyone else. It will not belong to Palestine nor Israel it will be a land to all, a free zone. Only in this way, the land will be respected and all who wish to enter and pray will be able to go there. The religious citing of all religions will be protected by international actors since they are of importance for all of the world.

The question of statehood is also an important one because "a state is a sovereign self-governing political entity". ("State versus Nation", pp.1) It is the political mean that governs a territory. (Luxenberg, Alan pp.1) The question of the Palestine territory has been and still is one of the greatest problems to be solved. And the question is whether Palestine is a state? (Ortiz, Alejansro Montero, pp. 2)

Being considered as a state would be beneficial for the Palestinians, and advance the negotiations for the 
resolution of the conflict. However, in the international community and as a subject to international law, a state depends on four requirements, a territory, a population, a government, and sovereignty. The territory represents the physical space, it can be land, sea or air where the sovereignty or jurisdiction of the state is presented. The territory and the population are the most characteristic elements of a state. The length of the territory, the frontiers even if they are not defined and the existence of a conflict should not be an obstacle to the creation of a state. (Ortiz, Alejandro Montero, pp. 17)

The four criteria discussed above were presented in Montevideo Convention of 1932 . The first criteria is the population in the case of Palestine is met without any doubt. The second one, defined territory, the UN has adopted a resolution on the frontiers since 1947. Resolution 242 of 22 November 1967 called for Israel to withdraw from the occupied territories and return to the 1949 Armistice lines. If occupying territories is taken as an argument against granting a statehood than it should apply to other states that have debated frontiers like China, India, Morocco, Cyprus and etc. If Palestine has to be a non-state than Israel should not be a state as well. Third criteria a government. There is a general recognition that under President Abbas and Prime Minister Sayed the Palestinian Authority (PA) has made a progress in terms of democratic processes, they have received the highest grade for democracy so they can be acknowledged as representatives of the democratic government. And in regard to the fourth criteria which is the capacity to enter the international relations, the Palestinian Authority has entered into many bilateral and multilateral relationships with the international community including the relationship with the EU. (Emerson Michael, pp.2) Regarding the above, it can be summarized that Palestine can be a state even though it still does not have affirmative borders. Under the International law it can be concluded that Palestine has fulfilled the requirements of the four criteria so it can be a state, and if anybody goes against this statement than what applies for one should apply for all states.

Also in support of the argument that Palestine is a state we can use the Constitutive theory of statehood. This theory states that an entity is a state if it is recognized by other states. Although this theory leads to extreme subjectivity. (Crawford James, pp. 309) But it still proves the obvious that Palestine is a state. Also to be noted is that 135 members of the UN have recognized Palestine as a state and the last being Sweden. (Tharoor Ishaan, pp.1)

\subsubsection{Zionism}

Zionism is a modern political movement. Its leading idea is that the Jewish people as a national group should be entitled to their own state and therefore the homeland should be Israel. Zionism was born as an idea due to European anti-Semitism. Theodor Herzl is the founder. The holocaust in Europe enhanced, even more, the support of the idea for a Jewish state. Zionism is a civil non-religious movement but it uses Jewish religious beliefs and attachments to Jerusalem to motivate the Jews. The politics of Zionism was influenced by nationalist and colonial ideas. ("Israeli - Palestinian conflict", pp.2) And it represents one of the triggers for the expansion of the Israeli-Palestinian conflict.

\subsubsection{Jerusalem}

With the UN 1947 allocation, Jerusalem should have become an international zone. In 1948 during the ArabIsraeli war, Israel took control of western Jerusalem, while Jordan took control of the eastern part of Jerusalem including the Old walled city containing important Jewish, Muslim and Christian religious objects. Furthermore, the 1949 treaty cut the city into two parts. In June 1967 Israel took East Jerusalem from Jordan and since then it regards it as its capital. The international community considers East Jerusalem as part of the West Bank. Palestinians regard East Jerusalem as the capital of Palestine. (Beinin, Joel, and Hajjar, Lisa, pp. 7) Jerusalem is one of the oldest cities in the world, it is a Holy City and a center for the three religions but it is also the aim of national aspirations and represents the key to a political resolution. (Abuzayyad Ziad, Schenker Hillel, Ross Ingrid, pp. 2) Therefore as mentioned above Jerusalem should be a free entity, without any outside influence, a holy place where people can pray and visit. This way the city will be restored with peace and security and will not be a trigger for the continuation of the conflict.

\section{THE FAILURE OF THE OSLO ACCORD AND THE CHAOS OF DESPERATION THAT FOLLOWED}

Israel and Palestine signed a declaration of Principle on Interim Self-Government Arrangement or the "Oslo Accord" at the White House. Israel accepted the Palestine Liberation Organization (PLO) as the representative of Palestine, and PLO recognized Israel. Both sides agreed that the Palestinian Authority (PA) would have a governmental responsibility in the West Bank and Gaza over 5 years. President Clinton role in the Oslo Accord was limited, his administration was more concentrated in achieving the Israeli-Lebanese agreement which isolated Iraq and Iran the opponents of the peace process. An Israeli-Jordanian peace 
treaty was concluded in 1994. In May 1994 Cairo Agreement, obliged Israeli withdrawal from Gaza and Jericho or the Taba (Oslo II). Oslo II divided the West Bank into two parts under Israeli control with Palestinian civil administration it also presented provisions for elections, civil/legal affairs, bilateral relations and cooperation on various issues. ("The Oslo Accords and the Arab-Israeli Peace Process") In November 1995 Rabin (Israeli Prime Minister) was assassinated by Amir, Israeli who opposed the Accord. His murder was followed by Hamas attacks. The new Prime Minister of Israel Netanyahu was against Palestinian statehood and refused to retreat from the occupied territories. On January 1997 with US help Israel and PA signed Hebron Protocol which provided for the transfer of most of Hebron to Palestine. In October 1998 Clinton invited Netanyahu and Arafat at the Wye River Plantation where they negotiated the Wye Memorandum and Israeli withdrawal from the West Bank. The implementation of the Memorandum brought down Netanyahu government. In May 1999 Barak came to power, and both parties signed Sharm al-Shaykh Memorandum that committed permanent status negotiations. The future meetings did not achieve anything significant and by December the Palestinians stopped negotiations. Clinton requested a Summit at Camp David in 2000, Barak and Arafat wanted to reach an agreement on the West Bank and Gaza Strip. Camp David failed, because both parties could not agree on the borders, and the recognition of Palestine refugees'. On September 28 new riots erupted that led to al-Aqsa Intifada. ("The Oslo Accords and the ArabIsraeli Peace Process") In September 2000, the violence escalated and lasted five years which led to Israel disengagement from Gaza. In 2006 Israel demanded Hamas to accept previous agreements between both and recognize Israel. This led to renewed violence, with Hamas taking full control of Gaza and Israel imposing a naval blockade on the Gaza Strip. The tensions between Israel and Hamas who gained financial and political support from Iran escalated until late 2008 when Israel launched military operations. By February 2009, a cease-fire was signed with international mediation (Ortiz, Alejandro Montero, pp. 7) The Oslo Accord I and II were not successful due to the fact that both sides during all of this negations were never willingly met, both sides were never prepared to discuss compromises and that is why the negotiations and agreements failed. Both sides should be prepared first to recognize each other as states and nations, discuss the situation with the borders and the best scenario is to oblige by the UN Resolution from 1947 and the city of Jerusalem to be an international territory a free zone, or a "Holy land" for all the people.

\section{UNITED NATIONS INVOLVEMENT IN THE CONFLICT}

As mentioned previously the relationship between Palestine and the United Nations begun in November 1947 when the UN decided to divide Palestine territory between the two communities the Jews and the Palestinian Arabs. The Jews were mostly immigrants who had fled persecution and settled in what they regarded as their historic homeland, the Palestinians were the country's indigenous residents. (Barak Oren, pp. 721) But the Palestinians did not accept the UN proposal due to the percentage of the land which was decided to be given to both sides and also due to the borders and the capital.

Palestine and the United Nations have a long history, Palestine for many years pursued to gain full membership in the UN because it will be internationally recognized as a state. This pursues resulted in the creation of a committee in the organization specified to solve the Palestinian question. In1975 the UN General Assembly with Resolution 3376 established the Committee on the Exercise of the Inalienable Rights of the Palestine People (CEIRPP) and requested for a recommendation of a program for the Palestinians to be able to exercise their rights to self-determination, national independence, and sovereignty. Previously in resolution 3236, the General Assembly had already recognized the above. (Ortiz, Alejandro Montero, pp. 9) Furthermore, in 2011 the Palestinian Authority (PA) attempt to gain UN membership as a country once again failed due to the influence of the USA and its veto power. In November 2012, the Palestinian representation in the UN became a non-member observer State, and the title was changed from "Palestine (represented by PLO)" to the State of Palestine. (Ortiz, Alejandro Montero, pp. 8) In November 2012 the UN General Assembly voted to recognize Palestine as a non-member state in the UN on the basis of the 1967 borders with East Jerusalem as its Capital. (Abuzayyad Ziad, Schenker Hillel, Ross Ingrid, pp. 2) Recognizing Palestine as a state in the International Community is not just of important significance to it but it is significant in resolving the conflict once and for all and bringing peace to the region. Because if Palestine is recognized as a state then both of them will be equal when sitting on the negotiating table.

The role of the international community in this process it is crucial because it is directly linked to the outcome of the conflict meaning that without the influence of the International Community both parties will never seat on the same table and discuss anything. A couple of UN Security Council Resolutions have focused on four issues in settling the conflict: making changes of the current situation, stopping the violation and destruction of Muslim places of worship, reducing/prosecuting the acts of violence against Palestinians and discussing the Israeli's undermining of the peace process in the Middle East. Also, the UN Security Council Resolutions have pointed out to Israel to stop with legislative and administrative acts used to change Jerusalem. But Israel has refused to act in accordance with international law. (Abuzayyad Ziad, Schenker Hillel, Ross Ingrid, 
pp. 6-7) Israel is not respecting the International actors since it has the backup of the US. To continue with, another important issue is that up until 1949 approximately 650-700.000 Palestinians became refugees due to Israeli forced displacement, fighting's, and massacres and ended up in the neighboring countries, the West Bank and the Gaza Strip. The UN created the UN Relief and Works Agency for Palestine Refugees (UNRWA) which in June 2004 listed almost 4.2 million Palestinian refugees. (Pressman, Jeremy, pp.4- 5) Among the above issues, the situation with the refugees is the most serious since the numbers are extreme and growing day by day. Refugees live in horrible conditions with no shelters or food, no education, and healthcare and we are talking about 4 million refugees only from this conflict, and they are not the only refugees there are the Syrian refugees in the region due to the conflict in Syria and from the other neighboring countries. Therefore this problem is escalating and it should be regarded with extreme seriousness.

\section{A TWO-STATE SOLUTION (AN ILLUSION OR A FUTURE REALITY)}

Israel has always claimed it wants a two-state solution but its actions have shown the opposite. Israel will negotiate the creation of Palestine only if the Palestinians accept Israel and agree to direct bilateral negotiations without conditions. This is very controversial because Israel refuses to treat Palestine as an equal actor. Therefore, Israel is not willing to accept a Palestinian state, and it does not want negotiations. (Ortiz, Alejandro Montero, pp. 12)

Solutions in this kind of conflicts are with the win-lose or win-win outcome. But usually the outcomes are lose-lose, and both sides don't want compromise because they want to lose the least if it is possible and the peace process is prolonged for this reason. Conflicts do not end, they only change the goal, from violence to politics. ("The Israeli-Palestinian Conflict: Historical and Prospective Intervention Analyses", pp.9)

In 2002 Bush administration supported the two-state solution and the International community approved regional recognition and a security package for Israel. Also, there was a Palestinian sovereignty limitation in order Palestine to continue with the demilitarization reform. ("The Israeli-Palestinian Conflict: Historical and Prospective Intervention Analyses", pp.6) Bush presented the Quartet Ministerial Statement for a two-state solution. A peace will be achieved when the Palestinians introduce a leadership that will oppose violence and will build democracy, and when Israel will support a democratic Palestinian state. When both parties accept the negotiated settlement, the Quartet will assist and help in the implementation of the plan with a realistic timeline. A Performance progress will be required in the period of the negotiations. The settlement will result in Palestinian independent and democratic state living in peace and security with Israel and its other neighbors. ("A performance-based Roadmap to a permanent Two-state solution to the IsraelPalestinian Conflict", pp.1) At the end of November 2007, the Bush administration conducted an international conference in Annapolis where both parties Israel and Palestine reached a "Joint Understanding" and launched bilateral negotiations to conclude a peace treaty by the end of 2008 and to implement the Roadmap. But both parties are operating under inner political restrains and they disagree on many issues. (Migdalovitz Carol, pp. 1) Therefore the negotiations were with a lose-lose outcome for both sides. Since both sides did not want to compromise, and no compromise no solution.

The Palestinian response to the conflict has always been disintegrated and unorganized. The community was never united and it never cooperated, they were incapable to create neighborhood committees, the role of the PA was never clear and unable to confront Israel. (Abuzayyad Ziad, Schenker Hillel, Ross Ingrid, pp. 7) But the problem it is not just inside Palestine, the problem lies in Israel politics too. Israel is using the weakness of Palestinian authority and it is using it to its advantage even though it does not want to settle the situation because of the outcome as they see it will be a lose-win situation. If Israel recognizes Palestine then it will lose its power over the occupied territories, also it will most probably lose power over Jerusalem if the conflict resolves with Jerusalem being an independent entity and if there is another scenario with Jerusalem being divided between the two still Israel will have to retreat from the occupied territories and as mentioned above Israel for many years played the card of resettling the areas that it invaded.

The conflict must be solved because the casualties that it has taken for the past century are devastating. There are two scenarios for the future. The first scenario will be a political agreement that would end the conflict. East and West Jerusalem would either be separated with minimum cooperation or Jerusalem could become an open city with two municipal governments, with a joint leading council and a joint administration. The second scenario will have no political solution and will have a continuation of more settlers coming in East Jerusalem and more attempts to reduce the proportion of the Palestinians to $28-32 \%$. (Abuzayyad Ziad, Schenker Hillel, Ross Ingrid, pp. 8) As mentioned previously the first scenario is most probable and it should be supported by the International Community because the second scenario is a continuation of the present time situation. 
If the two-state option is not realized in the future, there is great danger that the conflict will be converted from a national or political to religious. Which will be impossible to resolve. (Abuzayyad Ziad, Schenker Hillel, Ross Ingrid, pp. 2) If the conflict escalates in a religious one then there is no resolving it will most probably spill in the other parts of the region as well as to other parts of the world. This possible third scenario should never occur because it will lead to WWIII. The two-state solution is the most probable and the most realistic solution to this conflict.

\section{US-ISRAELI RELATIONS AND THE US INFLUENCE IN THE PROCESS}

The US has always been part of the Israeli-Palestinian peace process. The questions that follow is why negotiations lead by them always failed? Aldo partly answered above, it may be due to bad timing, bad deadlines, insufficient preparation, insufficient attention from US and etc. The Oslo Accord would have been successful if it had it not been for the assassination of the Israeli Prime Minister. The Wye River Memorandum would have been implemented if only the Israeli labor Party had joined Netanyahu's coalition. The Camp David summit would have succeeded if the US had been less sensitive to Israel. (Thrall Nathan, pp. 1) But the if paradigm is not so much important since it is obvious that the negotiations failed due to the conflicting sides unwillingness to negotiate firmly and go through with the objectives in the agreement. Israel and Palestine don't want to settle with a lose-lose situation even though it will be a win-win outcome. They believe that by settling and agreeing to certain rules they will lose and the other one will gain more but instead, they don't look at the win-win situation of resolving the 100-year long problem. Both parties will win by becoming recognized states between each other and recognized by the International Community, having peace and leaving in prosperity.

Israel has always been supported by the US and it has always had a backup plan, of course when it has a strong power by its side. And maybe that is the reason why Israel is feeling so secure and confident. Maybe the reasons for the failure of the negotiations should be placed in the hands of the US. They should finally try two options with Israel and see which one works. First offering Israel normalization with most Arab Islamic states, upgrading relations with Europe, US security guarantees, and increased financial and military assistance. But for Israel these motivations are poor. The second option is to make the fallback worse instead of rewarding Israel to punish it, (if you don't do as you are told you will have a drawback). For example, in 1956 President Eisenhower following the Suez crisis threatened economic sanctions in order Israel to withdraw from Sinai and Gaza. In 1975 President Ford revised US relations with Israel and it did not provide it with new arms until it agreed to a Sini withdrawal. President Carter terminated US military assistance until Israel did not evacuate Lebanon in1977. (Thrall Nathan, pp. 6) Also, this practice was used by the EC towards Israel and Palestine when it called for an Israeli withdrawal from all territories occupied during the 1967 Arab-Israeli war. Since 1999 the EU has placed political conditions on its aid to shape the development of Palestinian institutions, it has prioritized judicial and electoral reform, transparency of public financing, restructuring of the civil service and the security sector. ("Europe's Role in the Palestinian -Israeli Conflict", pp.5) These were excellent political and diplomatic acts of threats to put the balance on some situations by the US and the EU. And it is without a doubt that US can settle the issue with the help of the EU and the UN. They can force the two sides to sit on the same table and negotiate the terms and of course once and for all resolve the issue with the borders and the refugees by placing them in the corner.

Furthermore, Israel continues with its coherent political ideology its unilateralism and the thrust to expand to new territories. The conflict continues to suffer from the failure of Israel to be rationale and to create stable and mature political process. The influence of certain ideologies obstructs the territorial progress based on removing settlements. These two factors guarantee the failure of the peace efforts and pressures from the International, legal, political, and economic communities will increase on Israel. (Alpher Yossi, pp. 11-12) But Israel still has the US factor by its side, the new presidency seems to be on the Israeli side and the political actions and wording by the new administration whether used deliberately or not is placing a lot of fallback on US foreign policy and uncertainty in the eyes of the International Community.

US President Donald Trump officially recognized Jerusalem as the capital of Israel, reversing nearly 70 years of US foreign policy and placed the US on the opposite side. While Trump wanted to clear the name of the previous leaders and make changes, his signed proclamation was deranged with warnings and exclusions that make his policy confusing. No doubt this proclamation is intended to serve as a fence because it avoids taking an affirmative position on the controversial implications of the decision. (Anderson R. Scott, pp. 1-2)

"Today actions - recognizing Jerusalem as Israel's capital and announcing the relocation of our embassy - do not reflect a departure from the strong commitment of the United States to facilitating a lasting peace agreement. The United States continues to take no position on any final status issues. The specific boundaries of Israeli sovereignty in Jerusalem are subject to final status negotiations between the parties. The United States is not taking a position on boundaries or borders". (Anderson 
R. Scott, pp. 1-2)

Therefore the president was clear that the question of who has ultimate sovereignty over Jerusalem should be negotiated. In the interim, the US recognized Israel sovereignty over some part of Jerusalem enough for Jerusalem to be Israel capital but did not specify which part. The President refuses to specify rules or boundaries points to West Jerusalem. (Anderson R. Scott, pp. 1-2) But this is all just gassing of possibilities of what his words meant. Furthermore, US president Donald Trump threatened to cut off financial aid to all who will vote for the draft United Nations resolution for the US to withdraw its decision to recognize Jerusalem as Israel's capital. (Rampton Roberta, Nichols Michelle pp.1) The sudden change in US foreign policy due to this precise conflict it is confusing for many. And it is very debatable what the President was trying to achieve because as it was understood by the Arab states, by Palestine and even the International Community it is creating a further and deeper dead pool for the conflict. Therefore the US foreign policy as it stands will not help in solving the problem, maybe the chance is given to the UN and the EU to be the main actors in resolving the conflict.

\section{CONCLUDING POSSIBLE SOLUTIONS TO THE CONFLICT}

Israel and Palestine are prisoners of their historical narratives and victims of the past. Although the historical narratives form part of the national identity and should be preserved as their national heritage they should not deprive them of the future. (Bar-Siman-Tov Yaacov, pp. 21) Two states for two nations is the only solution of the conflict created by two national movements fighting for the same territory. If there is one binational state for the two nations each of them would want to dominate over the other. Therefore, the Trump administration should preserve the two-state solution and the outcome even if it is not visible. All or nothing diplomacy will not harvest anything. The absence of hope has placed both sides on the defensive side. Only radical's ideas gain power as the divergence deepens. (Makovsky David and Ross Dennis, pp.45) Ending the deadlock and restoring a sense of possibility remains essential to preserving a realistic endgame of two states for two people. As an idea, the Trump administration could ask the two parties and Arab leaders to present their ideas for progress and solution and could try to shape an initiative based on that. (Makovsky David and Ross Dennis, pp.6)

Recovering the peace process requires mutual confidence based on a compromise that meets the needs and validates the identities of both people. (Kelman C. Herbert, pp. 287) Mutual commitment to compromise offers both sides the opportunity for a better future, a secure, peaceful and prosperous existence, cooperation in various spheres. Kelman suggests that both groups would have a boundless identity based on the distinction between country and state. Each group could be attached and identified with the entire country as a geographical focus with historical memory and current activity while claiming ownership of and statehood in only part of that country. (Kelman C. Herbert, pp. 301) Although the idea is very interesting, in this precise conflict only specific ground rules will be applicable and respected, because as it is obvious both sides don't want to negotiate and compromise. Therefore the only possible solution here is the International Community to present the plan and apply it with their surveillance until both sides are convinced that this kind of solution is applicable and acceptable.

Resolution of the Israeli-Palestinian conflict is visible only if the representatives of the two nations sit down, discuss and resolve the issues within their own governments, then continue on with placing the open cards on the table with mediators from the US, UN, and EU. Drawing the borders upon the Resolution from 1947, restoring peace, stability and economic prosperity in the area without military establishments from both sides. Both nations to acknowledge themselves as nations and their statehood and of course to be recognized as such by the International actors. To continue with, Jerusalem to be a free entity a "Holy Land" to all the nations and religions. To be governed by a Council with joint administration and leadership but only for issues that are of importance to the city, an example presented by Abuzayyad, Schenker, and Ross. The citizens living in the area will be free to choose what nation and religion they will belong, but still, they will live in a free zone area. Going step by step with this proposal Israel and Palestine will wage towards peace and prosperity, instead of the desperation they live now.

\section{REFERENCE LIST}

Abuzayyad Ziad, Schenker Hillel, Ross Ingrid. (2013) "Jerusalem: Still Key to Any Future Israeli-Palestinian Agreement”. International Policy Analysis. Friedrich Ebert Stiftung. http://library.fes.de/pdf- 
files/iez/09711.pdf

Alpher Yossi. (2005), "The Future of the Israeli-Palestinian Conflict. Critical trends affecting Israel". United States Institute of Peace Special Report. https://www.usip.org/publications/2005/09/future-israelipalestinian-conflict-critical-trends-affecting-israel

Anderson, R. Scott. (2017) “Trump's Jerusalem Policy is More Ambiguous than it seems'. http://foreignpolicy.com/2017/12/11/trumps-jerusalem-policy-is-more-ambiguous-than-it-seems/

"A performance based Roadmap to a permanent Two-state solution to the Israel-Palestinian Conflict" (2003) US Department of State ARCHIVE. https://2001-2009.state.gov/r/pa/prs/ps/2003/20062.htm

Barak Oren. (2010) "The Failure of the Israeli-Palestinian Peace Process, 1993-2000". Journal of Peace Research. Vol.42 No. 6 Nov., 2005 Sage Publications Ltd http://www.jstor.org/stable/30042415

Bar-Siman-Tov Yaacov. (2010). "Barriers to Peace in the Israeli-Palestinian Conflict". The Jerusalem Institute for Israel Studies. Konrad Adenauer Stiftung. http://en.jerusaleminstitute.org.il/.upload/barries-engsummary.pdf

Belnin Joel and Hajjar, Lisa. (2014). "Palestine, Israel and the Arab-Israeli Conflict a Primer". Middle Eat Research and Information Project. https://web.stanford.edu/group/sper/images/PalestineIsrael Primer MERIP.pdf

Crawford, James. (1990) “The Creation of the State of Palestine: Too Much Too Soon?” EJIL. http://www.ejil.org/pdfs/1/1/1137.pdf

Emerson, Michael. (2011). "The political and legal logic for Palestinian Statehood". CEPS Commentary. https://www.ceps.eu/publications/political-and-legal-logic-palestinian-statehood

"Europe's Role in the Palestinian -Israeli Conflict" (2008) European Union Center of North Carolina EU Briefings http://europe.unc.edu/wp-content/uploads/2013/08/Brief6-0803-palestinian-israeli-conflict.pdf

"Israeli - Palestinian conflict". CAABU.

https://www.caabu.org/sites/default/files/resources/History\%20of\%20lsrael\%20Palestine.pdf

Kelman C. Herbert. (2007). "The Israeli-Palestinian Peace Process and its Vicissitudes". Insights from Attitude theory. Harvard University. American Psychologist Vol.62. No.4, https://scholar.harvard.edu/files/hckelman/files/Vicissitudes.pdf

Luxenberg, Alan. "Ten Things Students Need to Know About the Origins of Israel and Palestine". (2008) https://www.fpri.org/article/2008/04/ten-things-students-need-to-know-about-the-origins-of-israel-andpalestine/

Makovsky, David and Ross, Dennis. (2017) "Toward a New Paradigm for addressing the Israeli-Palestinian Conflict". Policy notes from the Trump administration. The Washington Institute near East Policy. No.32 http://www.washingtoninstitute.org/uploads/Documents/pubs/Transition2017-MEPP.pdf

Migdalovitz, Carol. (2007). "Israeli-Palestinian Peace Process: the Annapolis Conference". CRS Report for Congress https://fas.org/sgp/crs/mideast/RS22768.pdf

Ortiz, Alejansro Montero. (2015). "The Palestinian -Israeli conflict: An analysis of Palestine's Bid for Statehood". CEI INTERNATIONAL AFFAIRS - N 7/2015, http://diposit.ub.edu/dspace/bitstream/2445/65843/1/Alejandro Montero TFM.pdf

Pressman Jeremy. (2005). "A Brief History of the Arab-Israeli Conflict". http://web.uconn.edu/polisci/people/faculty/doc/history pressman.pdf

Rampton Roberta, Nichols Michelle. (2017) "Trump threatens to cut aid to UN members over Jerusalem vote". Reuters. https://www.reuters.com/article/us-trump-israel-un/trump-threatens-to-cut-aid-to-u-nmembers-over-jerusalem-vote-idUSKBN1EE2A3

"State versus Nation". United States Institute of Peace. https://www.usip.org/glossary/state-versus-nation

Tharoor, Ishaan. (2014) "Map: The Countries that recognize Palestine as a state". The Washington Post. https://www.washingtonpost.com/news/worldviews/wp/2014/11/07/map-the-countries-that-recognizepalestine-as-a-state/?utm term=.5b9d4b06f33e

"The Balfour Declaration: A century of injustice". https://fundraise.interpal.org/specials/balfour100/?gclid=EAlalQobChMlocGfu7Ss2AIVGluyCh1fiAuhE AAYASAAEgJf4 D BwE 
IJASOS- International E-Journal of Advances in Social Sciences, Vol. IV, Issue 10, April 2018

"The Israeli-Palestinian Conflict: Historical and Prospective Intervention Analyses". (2002) Special Conflict Report. The Carter Center. www.cartercenter.org

"The Oslo Accords and the Arab-Israeli Peace Process". Office of the Historian https://history.state.gov/milestones/1993-2000/oslo

Thrall Nathan. "The possibility of a lasting deal seems as far away as ever- and the history of failed negotiations suggests it's largely because Israel prefers the status quo". (2017) the Guardian. https://www.theguardian.com/world/2017/may/16/the-real-reason-the-israel-palestine-peace-processalways-fails

"The World Fact book". Central Inelegance Agency. https://www.cia.gov/library/publications/the-worldfactbook/geos/is.html Dec.12, 2017 